ISSN 0258-7122

Bangladesh J. Agril. Res. 33(3) : 459-468, September 2008

\title{
RETURNS TO INVESTMENT ON RESEARCH AND DEVELOPMENT OF SOIL BORNE DISEASE MANAGEMENT STRATEGY FOR BRINJAL IN BANGLADESH
}

\author{
MAHMUdA AKTER ${ }^{1}$, M. A. MONAYEM MiAH ${ }^{2}$ AND M. I. HOSSAIN ${ }^{3}$
}

\begin{abstract}
The study estimated the economic returns to the past investment on the development of two 1PM practices for controlling soil borne diseases in brinjal cultivation in Bangladesh. Economic surplus model with ex-post analysis was used to estimate returns to investment. The study showed that about $20.10 \%$ more brinjal production was made available due to adoption of IPM practices (i.e. use of poultry refuse and mustard oilcake) during 2002-2003. The yields of brinjal under IPM practices were 33\% and 34\% higher, respectively, over the non-IPM practices. Internal rate of return (IRR), net present value (NPV) and benefit cost ratio (BCR) of the past investments were estimated at 26\%, Tk. 436.21 million and 3.0, respectively. Under various assumptions on cost and return, the IRR ranged from 20 to $32 \%$ and BCR ranged from 2 to 5 . The investment in research and development of 1PM practices for managing soil born diseases in brinjal cultivation was found to be very efficient.
\end{abstract}

Key Words: Brinjal, soil borne disease, producer surplus, consumer surplus, expost analysis, returns to investment, internal rate of return, net present value

\section{Introduction}

Brinjal (Solanurn melongenum L.) is the second most important and popular vegetable in Bangladesh. It is usually grown throughout the year, but extensively grown in the winter. Ihe nutritive value of brinjal is quite high compared to tomato and other vegetables (Chowdury, 1976). The total area of brinjal is 60065 ha producing 358370 tons with an average yield of 5.97 ton/ha (BBS. 2004). In Bangladesh, brinjal farmers often fail to obtain the expected yield due to heavy damage caused by various insect-pests and diseases. Different species of fungal pathogens severely damage brinjal seedlings and plants as well. The diseases caused by these fungi are known as foot rot, damping off and stem rot. Initially, water-soaked blackened lesions appear at the base of the seedlings, then the affected portions become rotten and finally the plants wilt and die. High soil moisture and formation of crust on the soil surface enhance the attack of the pathogens and death of the brinjal plant (IPM-CRSP, 2004). Avoiding these

\footnotetext{
${ }^{1}$ Scientific Officer. Agricultural Economics Division, BARI. Joydehpur. Gazipur-1701. ${ }^{2}$ Senior Scientific Officer, Agricultural Economics Division. BARI. Joydebpur. Gazipur1701, ${ }^{3}$ Member Director (AERS), BARC, Farmgate, Dhaka, Bangladesh.
} 
diseases, farmers often use various kinds of materials and pesticides in attempts to control these diseases without success. As a result, farmers frequently face problems in raising brinjal seedlings and incur financial losses. The scientists of Bangladesh Agricultural Research Institute (BARI) under Integrated Pest Management Collaborative Research Support Programme (IPMCRSP) have developed some 1PM practices for controlling soil borne diseases (SBD) in brinjal cultivation. The 1PM practices are the use of decomposed poultry refuse (PR) and mustard oil cake (MOC) in the soil of seedbed as well as crop field. The uses of decomposed PR and MOC are highly effective in controlling $^{\mathrm{a}}$ SBD and rising brinjal crops without pesticides. At present, many farmers in different parts of Bangladesh are benefiting by using these two 1PM practices in brinjal cultivation. The present study thus look into consideration the benefits of past investment in developing two 1PM practices beginning in 2000, the year when brinjal farmers adopted these practices. The present study can provide valuable information for the policy makers, donors, researchers, and extension personnel on the benefit of the past investments in soil borne disease management in brinjal cultivation. The specific objectives of the study were to: (I) know the adoption of 1PM practices in brinjal cultivation; (i) estimate the yield advantage of brinjal cultivation under 1PM practices over non-IPM practice, and (ii) assess the efficiency of 1PM practices in brinjal production.

\section{Materials and Method}

An ex-post evaluation with the help of economic surplus model was adopted in this study to estimate the rate of returns to investment on research and development of 1PM practices for brinjal cultivation. The analysis was done under closed economy ${ }^{\mathrm{b}}$ situation.

\section{(a) Data collection and sources}

Two types of data are mainly needed for the analysis: i) market related data, and ii) research related data. The market related data of brinjal on annual prices and yearly production were collected from various issues of Bangladesh Bureau of

\footnotetext{
a The decomposed PR and MOC release organic acid in the soil that kills soil-inhabiting pathogens and root knot nematodes. Additionally, the organic matter of MOC and PR improves the soil fertility. The using rates of PR and MOC arc 3-5 t/ha and 300-500 $\mathrm{kg} / \mathrm{ha}$, respectively. Both these decomposed materials are properly mixed with the seedbed soil by spading.

${ }^{\mathrm{b}}$ The closed-economy commodity market is defined as a commodity that is totally produced and consumed domestically.
} 
Statistics (BBS). I)ey and Norton (1993) estimated the price elasticities of demand and supply for brinjal as -0.20 and 0.13 , respectively. Based on these estimates, a long-run price elasticity of supply of 0.13 and price elasticity of domestic demand $(\lambda<1)$ of -0.20 were assumed throughout the present study. The brinjal prices (Po) were converted to 2002-2003 constant prices using the Consumer Price Index (CPI) of middle-income group.

Research related data included rate of adoption of 1PM practices, annual area under 1PM practices, yield advantage of 1PM practices, input cost change (if any), and research \& extension expenditures. Research related data were obtained from the office of the 1PM- CRSP, BARI, Gazipur. The yearly expenditure for research and extension of 1PM practices is also converted to 2002-2003 constant prices using the CPI of the middle-income group. The cost of brinjal production under 1PM practice was higher (Tk. 39,340/ha) than that of non-1PM practice (Tk. 38,131/ha) due to use more number of labour. Therefore, the input cost change was Tk 1209/ha and this was deducted from total social benefit.

\section{(b) Analytical technique}

Theoretical framework of the model: The concept of economic surplus has been used to measure economic welfare and the changes in economic welfare from policy and other interventions. (Alston et al., and Currie et al., 1971). The social benefits to the research and extension of 1PM technology for brinjal production in Bangladesh are measured in terms of producers' and consumers' surpluses resulting from a shift in the supply curve, caused by an increase in productivity. This outward shift in the supply function results from an upward shift in the aggregate production function resulting from the adoption of 1PM technology br brinjal production. This relation is shown in Fig. 1 in which $D_{1}$ and $\mathrm{S}_{0}$ represent the actual market demand and pre-research supply curve, whereas $\mathrm{S}$ represents the post-research supply curve that would have existed due to the adoption of 1PM practice.

Assuming market equilibrium and closed-economy commodity market, the shift in the supply curve from $S$ to $S$ would increase consumers' surplus by Area $A B C+$ Area $P_{O} P_{n} B A$, the producers' surplus by Area AOC-Area $P_{O} P_{n} B A$, and the total social benefit or economic surplus by Area ABC + Area AOC (Fig. 1). The shift in the supply curve has decreased the price that made consumers better off. The change in consumers' surplus (benefits) can he measured as a monetary value. Besides, area AOC represents the benefits to the farmers from adopting the modern variety and can also be measured and quantified in monetary terms. Farmers will be benefited from the adoption of an intervention if Area AOC is 
greater than Area $\mathrm{P}_{0} \mathrm{P}_{n} \mathrm{BA}$. In the present case, the Area AOC is less than the Area $\mathrm{P}_{0} \mathrm{P}_{n} \mathrm{BA}$. The site of the two areas depends on the elasticities of the supply and demand curves and the site of the supply curve shift. The total social benefit from the adoption of 1PM technology is the summation of the change in consumers' surplus plus the change in producers' surplus minus the input cost change for adopting the new 1PM technology.

Figure 1. Closed-economy Economic Surplus Model

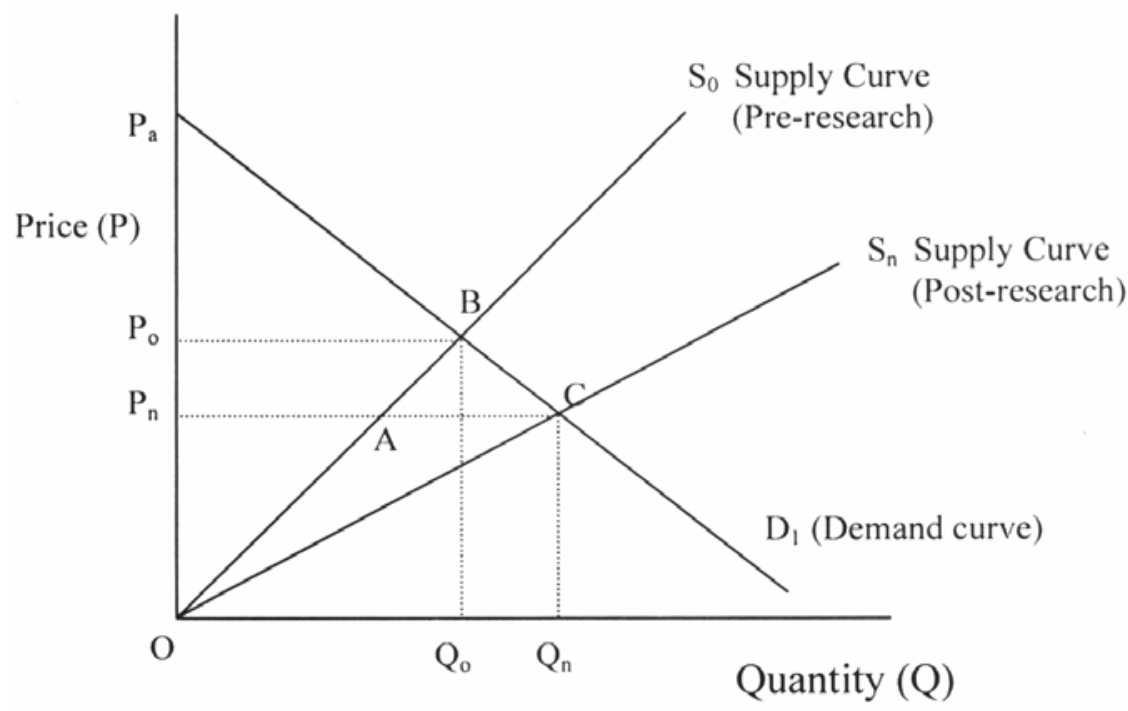

Distribution of Economic Benefits:

Change in consumer surplus/benefit

$=$ Area $\mathrm{ABC}+$ Area $\mathrm{P}_{0} \mathrm{P}_{\mathrm{n}} \mathrm{BA}$

Change in Producer surplus/benefit

$=$ Area AOC - Area $\mathrm{P}_{0} \mathrm{P}_{\mathrm{n}} \mathrm{BA}$

Change in total economic surplus/benefit

$=$ Area $\mathrm{ABC}+$ Area $\mathrm{P}_{0} \mathrm{P}_{\mathrm{n}} \mathrm{BA}$

Empirical model: The Akino and Hayarni (1975) approximation formula for calculating changes to producer and consumer economic surplus was used in this study. The approximation formula for calculating the change in economic surplus for a closed-economy situation (Fig. 1) is as follows:

(1) Area $\mathrm{ABC}=\left({ }^{1} / 2 \mathrm{P}_{\mathrm{n}} \mathrm{Q}_{\mathrm{n}}\right)\left(\left(\mathrm{K}(1+\lambda)^{2} /(\lambda+\eta)\right)\right)$

(2) Area $\mathrm{AOC}=\left(\mathrm{kP}_{\mathrm{n}} \mathrm{Q}_{\mathrm{n}}\right)$

(3) Area $\mathrm{P}_{\mathrm{O}} \mathrm{P}_{\mathrm{O}} \mathrm{BA}=\left(\left(\mathrm{P}_{\mathrm{n}} \mathrm{Q}_{\mathrm{n}} \mathrm{k}(1+\lambda)\right) /(\lambda+\eta)\right) \times\left(\left(1-\left({ }^{1} /{ }_{2} \mathrm{k}((1+\lambda) \eta)\right) /(\lambda+\eta)\right)-\left({ }^{1} /{ }_{2} \mathrm{k}(1+\lambda)\right)\right)$

Where,

$\mathrm{P}_{0}=$ Commodity price that would exist in absence of research 
$\mathrm{Q}_{0}=$ Quantity produced that would exist in absence of research

$\mathrm{P}_{\mathrm{n}}=$ Actual commodity price (existing market price)

$\mathrm{Q}_{\mathrm{n}}=$ Actual quantity (existing production)

$\mathrm{k}=$ Horizontal supply shifter

$\lambda=\quad$ Price elasticity of commodity supply

$\eta=$ Absolute price elasticity of the demand for the commodity. (For a closed-economy model, the estimated $\eta$ is used in the above formulae. For a small

open-economy model where the $\eta$ is perfectly elastic, use a sufficiently large number for $\eta$.)

The Sppluy Shifter (k): The overall yield advantage of improved practices over the local practices weighted by the area sown to the new practices and is called the supply shifter $(\mathrm{k})$. In estimating yield advantage, the yield of brinal under 1PM practices and non-IPM practice

$\left.k_{t}=\sum_{i=1}^{n}\left[1-\frac{Y_{t}}{Y_{i t}}\right)\right] \times A_{i t}$

was collected from field survey at Jessore and Annual Report of IPM-CRSP (Anon, 2004). The supply shifter $k$ is calculated as follows:

Where,

$\mathrm{Y}_{\mathrm{it}}=$ Yield of brinjal under 1PM practices in year $\mathrm{t}$

$\mathrm{Y}_{1}=$ Yield of brinjal under non-JPM practices in year $\mathrm{t}$

$\mathrm{A}_{\mathrm{it}}=$ Proportion of the total area sown to brinjal under 1PM practices in year $\mathrm{t}$

$\mathrm{n}=$ Number of 1PM practices.

Rate of return calculation: The IRR is calculated relating the total social benefit (TSB) minus an input cost change, if any, in each year to the research expenditure $(\mathrm{C})$ in each year and is the discount rate that results in a zero net present value of the benefits. The IRR is calculated as:

$o=\left[\sum_{t=1}^{n}\left(T S B_{t}-C_{t}\right)(1+I R R)^{-1}\right]$ 


\section{Results and Discussion}

\section{Adoption of 1PM practices in brinjal cultivation}

Two 1PM practices, namely PR and MOC were used to control soil borne diseases in brinjal cultivation. These technologies were released in 2000. The adoption of the selected IPM practices showed increasing trend and the share of brinjal cultivation adopting 1PM practices was 60\% during 2003 (Table 1). Hence, the total area sown under 1PM technology was 44994 ha.

Table 1. Status of adoption of 1PM practices in brinjal cultivation.

\begin{tabular}{|c|c|c|c|c|c|}
\hline \multirow[t]{2}{*}{ Item } & \multirow{2}{*}{$\begin{array}{c}\text { Releasing } \\
\text { year }\end{array}$} & \multicolumn{4}{|c|}{ \% adoption in different years } \\
\hline & & 2000 & 2001 & 2002 & 2003 \\
\hline \multicolumn{6}{|l|}{ 1PM practices to control SBD: } \\
\hline (i) Use of mustard oilcake (MOC) & 2000 & 5 & 15 & 25 & 30 \\
\hline (ii)Use of poultry refuse (PR) & 2000 & 10 & 15 & 30 & 30 \\
\hline $\begin{array}{l}\% \text { Brinjal area under to non-IPM } \\
\text { practices }\end{array}$ & & 85 & 70 & 45 & 40 \\
\hline \% Brinjal area under IPM practices & & 15 & 30 & 55 & 60 \\
\hline Area under brinjal production (ha) & \multicolumn{5}{|c|}{ Cropped area (ha) } \\
\hline (i) Under to non-IPM practices) & & 55298 & 48209 & 32830 & 29996 \\
\hline (ii) Under IPM practice & & 9759 & 20661 & 40125 & 44994 \\
\hline Total area (both practices) & & 65057 & 68870 & 72955 & 74990 \\
\hline
\end{tabular}

Source: IPM-CRSP, BARI, Gazipur.

\section{Yield advantage of brinjal under 1PM practices}

The 1PM practices in brinjal cultivation have replaced the non-IPM practice in the 1PM- CRSP areas starting in 2000. The potential yields of brinjal under the use of MOC and PR were recorded to be 7.45 and 7.65 t/ha, respectively. On the other hand, the productivity of brinjal under non-IPM practice was $5.02 \mathrm{t} / \mathrm{ha}$. Thus the potential relative yields of brinjal under the use of MOC and PR over non-IPM practices were found to be $23 \%$ and $34 \%$, respectively (Table 2).

Table 2. On-farm yields of brinjal by technology and yield advantage.

\begin{tabular}{l|c|c}
\hline \multicolumn{1}{c|}{ Technology } & \multicolumn{1}{|c|}{ Yield (t/ha) } & $\begin{array}{c}\text { Yield advantage over non- } \\
\text { IPM practice }\end{array}$ \\
\hline 1PM practice & \\
Use of mustard oilcake & 7.45 & 0.23 \\
Use of poultry refuse & 7.65 & 0.34 \\
\hline
\end{tabular}


The supply shifter $k$ was calculated using the equation (4) and found that $20.10 \%$ more brinjal production was made available during 2002-03 because of farmers' adoption of the 1PM practices (Table 3).

Table 3. Supply shifter (k) in diferent years for brinjal.

\begin{tabular}{r|l|l|r}
\hline Year & \multicolumn{1}{c|}{ \% brinjal area under } & \% bringal area under PR & Supply \\
\hline $1999-00$ & 0.05 & 0.10 & 0.051 \\
$2000-01$ & 0.15 & 0.15 & 0.100 \\
$2001-02$ & 0.25 & 0.30 & 0.185 \\
$2002-03$ & 0.30 & 0.30 & 0.201 \\
\hline
\end{tabular}

Example: k $(2002 / 03)=\{(1-\mathrm{LP}$ yield $/ \mathrm{MOC}$ yield $) * \%$ Area MOC $\}+\{(1-\mathrm{LP}$ yield/PR yield)* \% Area PR $\}=0.201$

\section{Rate of returns from investment}

Equations (1) through (3) were used to estimate the economic returns to the past investment on the development of two 1PM practices for controlling soil borne diseases in brinjal cultivation in Bangladesh. The equations were embedded into a computer spreadsheet for ease of computation. First, the yearly total social benefits were estimated using the closed economy model (Fig. 1). Using various parameters mentioned earlier, the internal rate of return (IRR), net present value (NPV) and benefit cost ratio (BCR) were estimated to be 26\%. Tk. 436.21 million, and 3.0, respectively (Table 4). The value of IRR indicates that each taka invested on the development of two 1PM practices for controlling soil borne diseases in brinjal cultivation, on an average, returns $26 \%$ annually from the date of the investment.

A sensitivity analyses was done on the economic returns to the past investment for the research and development of 1PM practices. When the yearly supply shifter $\mathrm{k}$ was decreased by $25 \%$, there was a decrease in the rate of return to $20 \%$. When the supply shifter $\mathrm{k}$ was increased by $25 \%$, the IRR increased to $32 \%$ and BCR stands to 5.0. When the expenditures were decreased by $25 \%$, the IRR and BCR remained the same. A simultaneous increase of $25 \%$ in the supply shifter and a 25\% decrease in expenditures gave rise to a 32\% IRR with BCR 5.0. Again, with the $50 \%$ increase and $50 \%$ decrease in the supply elasticity, there was no change in IRR (Table 5). 
Table 4. Rate of returns to the investment on research and development of 1PM practices for brinjal through ex-post analysis.

\begin{tabular}{|c|c|c|c|c|c|c|c|c|c|c|c|c|c|}
\hline Year & $\begin{array}{l}\text { Suppl } \\
\text { y } \\
\text { elasti } \\
\text { ci ty }\end{array}$ & \begin{tabular}{|c|} 
Dem \\
and \\
elasti \\
ci ty
\end{tabular} & $\begin{array}{l}\text { Suppl } \\
\text { y } \\
\text { Shifter } \\
(\mathrm{k})\end{array}$ & $\begin{array}{c}\text { Brinjal } \\
\text { producti } \\
\text { on (ton) } \\
\mathrm{Q}_{0}\end{array}$ & $\begin{array}{c}\text { Change } \\
\text { in } \\
\text { consum } \\
\text { er } \\
\text { surplus } \\
\text { (CS) }\end{array}$ & \begin{tabular}{|c|} 
Change in \\
producer \\
surplus \\
(PS)
\end{tabular} & $\begin{array}{l}\text { Change in } \\
\text { total surplus } \\
\text { (TS) }\end{array}$ & $\begin{array}{c}\text { Research } \\
\text { cost }(C)\end{array}$ & $\begin{array}{c}\text { Research } \\
\text { cost (C) }\end{array}$ & $\begin{array}{c}\text { Extension } \\
\text { cost }\end{array}$ & $\begin{array}{c}\text { Total input } \\
\text { cost } \\
\text { change }\end{array}$ & Total cost & Net benefit \\
\hline 1 & 2 & 3 & 4 & 5 & 6 & 7 & 8 & $9=(7+8)$ & 10 & 11 & 12 & $\begin{aligned} 13 & =(10+11 \\
& +12)\end{aligned}$ & $14=(9-13)$ \\
\hline $1990-91$ & 0.13 & 0.20 & 0 & 28251 & 185840 & 0 & 0 & 0 & 0 & 0 & 35027148 & 35027148 & -35027148 \\
\hline 1991-92 & 0.13 & 0.20 & 0 & 17045 & 185250 & 0 & 0 & 0 & 0 & 0 & 34874814 & 34874814 & -34874814 \\
\hline $1992-93$ & 0.13 & 0.20 & 0 & 8987 & 189245 & 0 & 0 & 0 & 0 & 0 & 35187945 & 35187945 & -35187945 \\
\hline $1993-94$ & 0.13 & 0.20 & 0 & 8694 & 188220 & 0 & 0 & 0 & 0 & 0 & 34946145 & 34946145 & -34946145 \\
\hline 1994-95 & 0.13 & 0.20 & 0 & 7995 & 187705 & 0 & 0 & 0 & 0 & 0 & 35220588 & 35220588 & -35220588 \\
\hline 1995-96 & 0.13 & 0.20 & 0 & 7524 & 188745 & 0 & 0 & 0 & 0 & 0 & 35613513 & 35613513 & -35613513 \\
\hline 1996-97 & 0.13 & 0.20 & 0 & 7300 & 191910 & 0 & 0 & 0 & 0 & 0 & 36226476 & 36226476 & -36226476 \\
\hline $1997-98$ & 0.13 & 0.20 & 0 & 6709 & 191525 & 0 & 0 & 0 & 0 & 0 & 36568623 & 36568623 & -36568623 \\
\hline 1998-99 & 0.13 & 0.20 & 0 & 7318 & 403730 & 0 & 0 & 0 & 104011 & 544050 & 70129840 & 48777901 & $-7077790 !$ \\
\hline 1999-00 & 0.13 & 0.20 & 0.051 & 641440 & 392340 & 328791342 & -194700209 & 134091133 & 126440 & 11798631 & 66728842 & 78653913 & 55437220 \\
\hline 2000-01 & 0.13 & 0.20 & 0.100 & 9108 & 415068 & 749748945 & -295949967 & 453798977 & 242365 & 24979149 & 58042316 & 83263830 & 370535147 \\
\hline 2001-02 & 0.13 & 0.20 & 0.185 & 8244 & 439688 & 507404462 & 401195797 & 908600259 & 504543 & 48511125 & 39186927 & 88202595 & 820397664 \\
\hline 2002-03 & 0.13 & 0.20 & 0.201 & 7600 & 444540 & 354820146 & 588273065 & 943093211 & 652383 & 54397746 & 35611572 & 90661701 & 852431510 \\
\hline
\end{tabular}

Source: Dey and Norton (1993); BBS, 2004; IPM-CRSP

Results: Internal rate of return 26\%; Net present value =Tk. 436.21 million: Benefit cost ratio =3.00 
Table 5. Sensitivity analysis on the returns to investment on research and development of PM practices for brinjal 


\section{Summary and Conclusion}

The study estimates the economic returns to the past investment on the development of two IPM practices for controlling soil borne diseases in brinjal cultivation in Bangladesh. The productivity of brinjal under 1PM practices was much higher than that of non-IPM practices. Ihe investment made for the research programme was found to be very efficient in terms of higher JRR and NVP. Due to adoption of 1PM practices, a large amount of brinjal was made available during 2002-2003. Sensitivity analysis revealed that the IRR of the programme ranged from $26 \%$ to $32 \%$ under various assumptions of the benefits and the research and extension expenditures. Simultaneous increase of supply shifter and decrease of expenditure gave higher IRR and BCR of brinjal cultivation implying that brinjal cultivation is profitable under 1PM practice. The study indicated that the research and extension of 1PM practices for brinjal cultivation presents a lucrative public investment opportunity. Therefore, both government and donors should continue their financial support and technical efforts to develop more 1PM technologies for brinjal cultivation. This also needs attention of researcher, extension personnel and policy makers.

\section{References}

Akino, M. and Y. Hayami. 1975. Efficiency and equity in public research: Rice breeding in Japan's economic development. American Journal of Agricullural Economics 57 (3): 1-10.

Alston, J. M., G.W. Norton and P.G. Pardey. 1995. Science under scarcity: Principles and practice for agricultural research evaluation and priority setting. Cornell University Press, Ithaka.

Anonymous. 1994. Integrated control of eggplant shoot and fruit borer (Leucinodes orbotialis C.) at Jessore, Annual Research Report, 1993-94, Bangladesh Agricultural Research Institute, Gzzipur, pp. 44-46

BI3S (Bangladesh Bureau of Statistics). 2004. Statistical Yearbook of Bangladesh, Ministry of Planning, Dhaka, Bangladesh.

Choudhury, B.1976. Vegetables ( $4^{\text {th }}$ edition), National Book of Trust, New Delhi. pp. 50-58.

Currie, J.M., J.A. Murphy and A. Schmitz. 1971. The concept of economic surplus and its use in economic analysis. Economic Journal 18: 741-798.

Dey, M. and G. Norton. 1993. Analysis of agricultural research priorities in Bangladesh. BARC. ISNAR 91(5): 1011-1020.

IPM-CRSP (Integrated Pest Management Collaborative Research Support Program. 2004. Soil amendment practices for managing soil-borne diseases to grow healthy seedling of vegetables and crops in Bangladesh, Bangladesh Site Extension Bulletin No.1. September 2004.

Peterson, W.L.1971, The returns to investment in agricultural research in the United States. In: W.l. Fishel, ed., Resources allocation in agricultural research. Minneapolis, University of Minnesota Press, USA. 